\title{
The European Union's Indicators of Social Inclusion
}

\author{
LAEKEN INDICATORS OF SOCIAL COHESION IN THE EUROPEAN UNION
}

\begin{tabular}{|c|c|c|}
\hline \multirow[b]{2}{*}{ Thematic area/indicator } & \multicolumn{2}{|c|}{ Breakdowns by: } \\
\hline & Age & Sex \\
\hline \multicolumn{3}{|l|}{ Primary indicators } \\
\hline \multicolumn{3}{|l|}{ Income } \\
\hline $\begin{array}{l}\text { 1. Low income rate after transfers threshold set at } 60 \% \text { of median } \\
\text { national equivalised income }\end{array}$ & Yes & Yes \\
\hline 1a. Low income rate after transfers with breakdowns by household type & $\begin{array}{l}\text { By house- } \\
\text { hold type }\end{array}$ & $\begin{array}{l}\text { By house- } \\
\text { hold type }\end{array}$ \\
\hline $\begin{array}{l}\text { 1b. Low income rate after transfers by work intensity of household } \\
\text { members }\end{array}$ & No & No \\
\hline $\begin{array}{l}\text { 1c. Low income rate after transfers with breakdowns by most } \\
\text { frequent activity states }\end{array}$ & Yes & Yes \\
\hline $\begin{array}{l}\text { 1d. Low income rate after transfers with breakdowns by housing } \\
\text { tenure status }\end{array}$ & Yes & Yes \\
\hline 2. Low income threshold (illustrative values) & No & No \\
\hline 3. Distribution of income (quintile 5/quintile 1 ) & No & No \\
\hline $\begin{array}{l}\text { 4. Persistence of low income (based on threshold of } 60 \% \text { of median } \\
\text { national equivalised income) }\end{array}$ & Yes & Yes \\
\hline $\begin{array}{l}\text { 5. Relative median low-income gap (difference between the median } \\
\text { income of persons below the low-income threshold and the threshold } \\
\text { of } 60 \% \text { of median national equivalised income) }\end{array}$ & Yes & Yes \\
\hline \multicolumn{3}{|l|}{ Employment } \\
\hline 6. Regional cohesion (dispersion of regional employment rates) & No & Yes \\
\hline $\begin{array}{l}\text { 7. Long-term unemployment rate (percentage of EAP that has been } \\
\text { unemployed for at least } 12 \text { months) }\end{array}$ & Yes & Yes \\
\hline 8a. Children (aged 0-17) living in jobless households & No & No \\
\hline 8b. Adults (aged 18-59) living in jobless households & No & Yes \\
\hline \multicolumn{3}{|l|}{ Education } \\
\hline 9. Early school leavers not in education or training & No & Yes \\
\hline 10. Fifteen-year-old students with low reading literacy scores & No & Yes \\
\hline \multicolumn{3}{|l|}{ Health } \\
\hline 11. Life expectancy at birth & No & Yes \\
\hline \multicolumn{3}{|l|}{ Employment } \\
\hline 12. Immigrant employment gap & Desirable & Yes \\
\hline
\end{tabular}


Breakdowns by:

Thematic area/indicator

Age

Sex

\section{Secondary indicators}

\section{Income}

13. Dispersion around the low-income threshold

Yes Yes

14. Low-income rate anchored at a moment in time

Yes Yes

15. Low-income rate before transfers, by sex

Yes Yes

16. Gini coefficient

No No

17. Persistence of low income (below $50 \%$ of median income)

Yes Yes

18. Women at risk of poverty

Yes Yes

\section{Employment}

19. Long-term unemployment share

Yes Yes

20. Very long-term unemployment rate (at least 24 months, as a

Yes

Yes percentage of the working population)

\section{Education}

21. Persons with low educational attainment

Yes

Yes

Source: ECLAC, 2007: 36 


\section{Notes}

1 At http://www.unrisd.org/; see the pages for social policy and development.

2 Two recent articles provide useful overviews of the multiple definitions of the concept and comparisons of its use in different policy settings (Hulse and Stone, 2007; Chan et al., 2006). Definitional distinctions were also an important theme in Beauvais and Jenson (2002), Jenson (1998) and Peace et al. (2005: 3-6).

3 The Treaty of Maastricht states that the objective of the Union is to 'promote economic and social progress which is balanced and sustainable, in particular through the creation of an area without internal frontiers, through the strengthening of economic and social cohesion and through the establishment of economic and monetary union ....' The treatment of social cohesion by Berger-Schmitt (2002), particularly the equality dimension, reflects an effort to develop measures for assessing the achievement of these goals, as is the work on social inclusion described in, inter alia., Marlier et al. (2006) and ECLAC (2007: chapter 2).

4 For this lineage see the discussions in Jenson (1998: 8ff.) and Chan et al. (2006: 275-77). See also Rajulton et al. (2007), who make an explicit link back to Durkheim.

5 Council of Europe, Parliamentary Assembly Recommendation 1355 (1998).

6 See www.cohesionsociale.gouv.fr/plan-cohesion-sociale/presentation/70.html, consulted 12 September 2007.

7 Cheong et al. (2007: 26ff.) provide an overview as well as references to the government reports.

8 Forrest and Kearns (2001) provide a useful review of how the two concepts have come to intersect in considerations of national level and neighbourhood level variables. The standard reference to the 'value' of networks is to Lin (2001: 19), who considers social capital to be an 'investment in social relations with expected returns in the marketplace'.

9 The standard reference to the 'value' of networks is to Lin (2001: 19), who considers social capital to be an 'investment in social relations with expected returns in the marketplace'.

10 It is interesting to note a certain ambiguity about where social capital fits in the history of ideas (Jenson, 1998; Ferlander, 2007: 115). Initial work on democracy in Italy (Putnam et al., 1993) was explicitly Tocquevillian in its gestures towards the 'founding fathers' and simultaneously liberal. However, over time, the Durkheimian roots and concerns about social order have been claimed (for example, Helliwell, 2005: 1, which references Durkheim's work on suicide) or identified (Bevort and Lallement, 2006).

11 A more up-beat assessment is provided by John Helliwell (2005), who also reviews the literature and finds a strong causal link, but his dependent variable is individual well-being. Thus, individuals with higher levels of social capital - defined as '.. trust in their neighbourhoods, their workplaces, their public services and their public servants' (Helliwell, 2005: 11) - reported higher levels of subjective well-being. This literature on individuals and their well-being, also being worked on by the OECD (for example, Boarini et al., 2006), is not discussed here.

12 The standard history is that both Pierre Bourdieu and James Coleman used the concept well before Robert Putnam (for example Bevort and Lallement, 2006). But economists also find the origins of social capital in research on networks in labour markets (an overview is in Durlauf and Fafchamps, 2004).

13 Political scientists and sociologists, such as Margaret Levi and Sidney Tarrow, discussed the possible negative consequences of social capital very quickly after the book on Italy appeared (see Jenson, 1998).

14 As Sara Ferlander says (2007: 116), 'in none of the outcomes is the importance of social connectedness so well established as in the case of health and well-being'. For a recent overview of the links between social capital and health outcomes see Health Policy Research, No. 12, September 2006. This is an issue of Health Canada's bulletin, entitled 'Social Capital and Health: Maximizing the Benefits', available at: http://www. hc-sc.gc.ca/sr-sr/pubs/hpr-rpms/bull/2006-capital-social-capital/index_e.html.

15 While the academic version of the argument was only published in 2006, it first appeared as a speech by the Bank's Vice-President for Development Policy in 2000 (Beauvais and Jenson, 2002: 14) and as a World Bank working paper the same year (Ritzen et al., 2000).

16 This is a quite general phenomenon, seen across several countries in Europe and North America (Flint and Kearns, 2006; Bradford, 2002).

17 A recent review of all these arguments is provided in the whole of OECD (2006) as well as Turok (2006) and Gordon (2006).

18 In this literature, as in that in which social cohesion is defined simply as social capital, there is recognition that social cohesion is not always 'good'. It may lead to exclusion, to closed communities and so on.

19 For example, in its report on the Plan de cohésion sociale [social cohesion policy] put into place by 
government in 2004, the French ministry can report on how well its goals for housing and job creation have been met, but not on how 'social cohesion' has been created (France, 2005).

20 In particular, the work reported by the OECD on social cohesion and cities tends either to find little relationship - cities with high crime rates are also cities, like London, with high rates of in-migration, tourism and so on (Turok, 2006: 359) - or that the causality runs from economic performance to social cohesion.

21 There is a large literature on how to measure trust. One popular source of measures is the public opinion survey (often the European or World Values Surveys or a specific national survey) that simply asks how much people trust each other or institutions. This simple measure has been rejected by others, who insist on operationalising differences among kinds of trust (for example, Nooteboom (2007: 46)). Appropriate attention to these theoretical and methodological points would render much of the existing and available data on levels of trust - which is already very limited - inadequate for cross-national comparison of small states.

22 This work was done in a broader context of developing a European System of Social Indicators. See . See http://www.gesis.org/en/services/data/social-indicators/eusi/

23 Here the measure of 'institutional quality' is not an objective one, as in Easterly et al. (2006), but an attitudinal one, drawn from surveys (Berger-Schmitt, 2002: 421).

24 This work gave rise to a set of indicators agreed at the Laeken Summit in 2001. Committees on social indicators and expert groups have been at work since then, giving rise most recently to the publication by Marlier et al. (2006), based on work done for the Luxembourg Presidency in 2005.

25 McNeil (2006) analyses three such quasi-concepts: social capital, the informal sector and sustainable development. 